\title{
KONFLIK AGRARIA DI KECAMATAN SEMBALUN KABUPATEN LOMBOK TIMUR NUSA TENGGARA BARAT 1979-2019
}

\author{
Dani Umaruddin \\ Progam Studi Ilmu Sejarah, Fakultas Ilmu Budaya, Universitas Udayana Bali \\ E-mail: daniumaruddin25@gmail.com
}

\begin{abstract}
ABSTRAK
Studi ini membahas tentang konflik agraria yang terjadi di Kecamatan Sembalun, Kabupaten Lombok Timur, Nusa Tenggara Barat dari tahun 1979-2019. Adapun permasalahan dalam studi ini adalah: 1) Mengapa terjadi konflik agraria di Kecamatan Sembalun? 2) Bagaimana bentuk-bentuk konflik agraria yang terjadi di Kecamatan Sembalun? Metode yang digunakan adalah Metode Sejarah Kritis. Sementara teori yang digunakan adalah Materialisme Dialektika Historis dari Karl Marx dan teori Konflik dari Ralf Dahrendorf. Hasil studi ini menunjukan bahwa konflik agraria di Kecamatan Sembalun tahun 1979-2019 merupakan konflik agraria struktural. Bentuknya adalah pertentangan klaim antara masyarakat adat Sembalun dengan pemerintah dan perusahaan mengenai siapa yang berhak atas akses pada tanah dan Sumber Daya Alam. Penyebab utama konflik adalah ketiadaan lahan masyarakat yang menjadi alat produksi mereka untuk memenuhi kebutuhan nafkah hidup materialnya. Hal itu disebabkan oleh praktik negarasasi (pengambilalihan lahan) yang dilakukan pemerintah dan menegasi sistem hukum adat dalam tata pengelolaan agraria di Sembalun. Konflik menjadi tidak mengusai ketika masyarakat petani Sembalun masif memertahankan lahannya, dan berupaya mengembalikan sistem hukum adat atau disebut negasi atas negasi.
\end{abstract}

Kata Kunci: Konflik Agraria, Masyarakat Sembalun, Materialisme Dialektika Historis.

\begin{abstract}
This study discusses agrarian conflicts that occurred in Sembalun District, East Lombok Regency, West Nusa Tenggara from 1979-2019. The problems in this study are: 1) Why are there agrarian conflicts in Sembalun District? 2) What are the forms of agrarian conflict that occurred in Sembalun District? The method used is the Critical Historical Method. Meanwhile, the theory used is Historical Dialectical Materialism from Karl Marx and Conflict theory from Ralf Dahrendorf. The results of this study indicate that the agrarian conflict in Sembalun District in 1979-2019 was a structural agrarian conflict. It takes the form of conflicting claims between the Sembalun indigenous peoples and the government and companies regarding who has the right to access land and natural resources. The main cause of the conflict is the lack of community land that becomes their means of production to meet their material subsistence needs. This is due to the practice of negarasasi (land acquisition) carried out by the government and negating the customary law system in agrarian management in Sembalun. Conflict becomes less powerful when the massive Sembalun peasant community defends their land, and tries to restore the customary law system or what is called negation over negation.
\end{abstract}

Keywords: Agrarian Conflict, Sembalun Society, Historical Dialectical Materialism. 


\section{PENDAHULUAN}

Konflik adalah suatu pertentangan antar kelompok atau perorangan yang berbeda kepentingan satu sama lain. Pertentangan kepentingan ini berbeda dalam intensitasnya tergantung pada sarana yang dipakai, dan konflik tidak bisa dipisahkan dari kehidupan sosial (Rosana, 2015: 216-217). Konflik agraria adalah suatu situasi proses interaksi (orang atau kelompok) yang masing-masing memerjuangkan kepentingannya atas objek yang sama, yaitu tanah dan bendabenda lain yang berkaitan dengan tanah, seperti air, udara, tanaman, dan juga tambang yang berada di atas tanah yang bersangkutan.

Konflik agraria di Indonesia sudah terjadi sejak masa kolonial. Hal itu muncul karena pemerintah kolonial mengembangkan kebijakan ekspansi perkebunan industri yang memaksa rakyat untuk menyerahkan tanahnya demi kepentingan tersebut. Pasca kemerdekaan, konflik agraria juga terjadi, terlebih pada masa pemerintahan Orde Baru. Pada masa Orde Baru ada dua bentuk konflik agraria yang umum terjadi: Pertama, konflik antara petani dengan korporasi akibat keluarnya Hak Guna Usaha (HGU) di atas tanah yang dikuasai oleh rakyat secara turun menurun. Kedua, konflik antara petani dengan pemerintah terkait dengan pembebasan lahan di atas tanah yang telah dikuasai atau dimiliki petani untuk pembangunan berbagai kepentingan umum (Astuti, 2012: 52).

Dalam studi ini khusus membahas mengenai konflik agraria yang terjadi di Kecamatan Sembalun, Lombok Timur, Nusa Tenggara Barat. Dipilihnya Kecamatan Sembalun sebagai lokasi penelitian (skup spasial), karena masyarakat Sembalun memiliki sejarah yang panjang dalam pengelolaan tanah ulayat. Namun kemudian terjadi konflik agraria berkepanjangan (Sembahulun \& Y.L. Franky, 2009: 144). Menurut penelitian terdahulu yang ditulis oleh Yamni (2015) dengan judul "Taman Suaka Marga Satwa Rinjani, Tanam Paksa Kopi, Taman Nasional Gunung Rinjani dan HGU: Negara(isasi) Tanah Masyarakat Adat Sembahulun dari Masa ke Masa." menjelaskan bahwa konflik agraria yang terjadi di Kecamatan Sembalun terjadi dari mulai pada masa Pemerintahan Hindia Belanda. Pemerintah Hindia Belanda mengeklaim secara sepihak terhadap tanah adat untuk dijadikan sebagai Taman Suaka Marga Satwa. Yamni telah memberikan pemikiran awal dengan menunjukkan proses sejarah dan bentuk-bentuk konflik agraria di Kecamatan Sembalun. Namun, sekup temporalnya sampai tahun 1999, sedangkan pada studi ini dimulai dari pemerintah Orde Baru memisahkan masyarakat adat dari lahannya pada tahun 1979 sampai pada tahun 2019 ketika masyarakat Sembalun mendapat dukungan penuh dari empat kepala desa yang berada di Kecamatan Sembalun. Dalam studi ini juga memperbaharuinya dengan menawarkan pemikiran alternatif melalui peminjaman atau penyerapan teori-teori strukturalisme yang relevan, yakni teori materialisme dialektika historis dari Karl Marx dan teori konflik dari Ralf Dahrendorf agar bisa menghasilkan karya yang menjelaskan secara lebih komprehensif.

Konflik agraria di Kecamatan Sembalun pada masa Pemerintah Orde Baru ini ditandai dengan menerbitkan UU No. 5 tahun 1979 tentang Pemerintahan Desa. Melalui UU tersebut, pemerintah Orde Baru secara sistematis meminggirkan pengaruh kepemimpinan adat dengan menghadirkan lebih kuat kepemimpinan birokrasi desa. Pengaruh dan kontrol birokrasi yang semakin kuat atas masyarakat 
adat, memudahhkan Orde Baru melanjutkan proyek kebijakan kolonialisme, yakni melakukan negaranisasi dan penghancuran memori sejarah masyarakat adat (Rozaki, 2016: 40). Praktek negaranisasi tanah adat dilakukan dengan mengubah status tanah masyarakat adat menjadi tanah milik negara. Hal itu terjadi pada 1980, ketika Dinas Kehutanan dan Perkebunan Kabupaten Lombok Timur mendatangkan proyek penanaman kopi, yang dibagikan kepada masyarakat adat di Sembalun dalam upaya untuk mengembalikan kejayaan kopi Arabika atau yang disebut Kawah Sembalun. Akan tetapi dalam pelaksanaannya, tanaman kopi tersebut gagal panen sehingga terjadilah pengambilalihan lahan milik masyarakat, karena dianggap berhutang atas kegagalan panen kopi yang ditanam. Akibat dari kasus pengambilalihan lahan ini banyak masyarakat jatuh miskin, sehingga banyak yang sampai menjadi buruh migran ke luar negeri sebagai Tenaga Kerja Indonesia (TKI) untuk menopang keberlangsungan hidup keluarganya (Fajar, 2014).

Tanah yang diambilalih tersebut, kemudian dikonsesi melalui HGU pada perusahaan PT. Sembalun Kusuma Emas (SKE), yang waktu itu berada di bawah pimpinan Tien Soeharto (Istri presiden Soeharto). PT. SKE pun mengklaim telah menguasai lahan di Sembalun seluas 555,56 hektar (PT. Sembalun Kusuma Emas, 2009). Sekalipun demikian pada 1998, runtuhnya Orde Baru rupanya memberi jalan pada kekuatan politik yang selama ini bersimpati pada hak-hak publik, serta budaya masyarakat adat. Era reformasi, bagi masyarakat adat hal itu ditandai dengan munculnya dua produk hukum: Pertama, UU No. 39 Tahun 1999 tentang Hak Asasi Manusia, terutama pasal 6 yang di dalamnya menyebutkan bahwa hak ulayat sebagai bagian dari identitas budaya masyarakat adat, layak diakui dan dilindungi. Kedua, Amandemen Kedua UUD 45 Tahun 2000 pasal 18b mengakui tentang keberadaan masyarakat hukum adat (Rozaki, 2016: 42-43).

Era reformasi juga mendorong munculnya kekuatan baru di Kecamatan Sembalun yang peduli terhadap hak-hak masyarakat adat. Hal itu ditandai dengan terbentuknya organisasi adat, seperti Aliansi Masyarakat Adat Nusantara (AMAN) (Rozaki, 2016:43). Selain itu, menurut keterangan Amaq Piran (2020) sejumlah organisasi tani juga hadir, seperti Serikat Petani Indonesia (SPI) dan Aliansi Gerakan Reforma Agraria (AGRA). Konteks semacam ini memunculkan kesadaran dan gerakan untuk melakukan klaim lahan di sekitar kawasan yang dikuasai PT. SKE, baik dengan cara pendudukan lahan ataupun berupa aksi demonstrasi.

Tahun 2014, menjadi awal dari terjadinya aksi demonstrasi tersebut saat perusahaan melakukan pematokan ulang lahan yang telah dikerjakan masyarakat. Perusahaan juga meminta masyarakat agar tidak lagi mengerjakan lahan tersebut. Masyarakat Sembalun pun menolak akan permintaan tersebut, dan kemudian melakukan aksi demonstrasi ke Kantor Camat Sembalun untuk mempertahankan ahannya. Aksi di tahun 2014 tersebut, mengawali rentetan aksi-aksi demonstrasi lanjutan sampai pada tahun 2019.

Uraian masalah di atas, memerlihatkan adanya sebuah korelasi sebab-akibat mengenai konflik agraria yang terjadi di Kecamatan Sembalun dari masa ke masa. Oleh karena itu, ruang lingkup permasalahan dalam studi ini dirumuskan dengan mengajukan dua buah pertanyaan penelitian, sebagai berikut: 1) Mengapa terjadi konflik agraria di Kecamatan Sembalun. 2) Bagaimana bentuk-bentuk konflik agraria yang terjadi di Kecamatan Sembalun. 
Teori yang digunakan dalam studi ini mengambil dari rumpun ilmu sosial. Sebagaimana yang dikatakan Kartodirdjo (1993: 3), bahwa fungsi ilmu sosial dalam ilmu sejarah adalah untuk menjawab pertanyaan 'mengapa,' serta membantu dalam menganalisis unsur dan faktor penyebab yang melatarbelakangi gejala sejarah. Atas dasar itu, studi ini memilih menggunakan kerangka teori sosiologi strukturalisme, yakni teori Materialisme Dialektika Historis dari Karl Marx dan teori Konflik dari Ralf Dahrendorf. Dalam analisis, teori Konflik Ralf Dahrendorf digunakan untuk menopang teori Materialisme Dialektika Historis Karl Marx. Artinya, semua teori akan dipakai dalam menganalisis permasalahan, tetapi teori Materialisme Dialektika Historis dari Karl Marx memiliki kedudukan yang utama.

Marx memetakan materialisme ke dalam materialisme dialetika dan materialisme historis. Materialisme dialektika merupakan ajaran Marx yang menyangkut hal ihwal alam semesta secara umum. Menurut Marx, perkembangan sejarah manusia tunduk pada watak materialistik dialektika. Sedangkan materialisme historis merupakan pandangan ekonomi terhadap sejarah. Kata historis ditempatkan Marx dengan maksud untuk menjelaskan berbagai tingkat perkembangan ekonomi masyarakat yang terjadi sepanjang zaman. Marx tetap konsekuen memakai kata historical materialisme untuk menunjukkan sikapnya yang bertentangan dengan filsafat idealisme (Irzum, 2015 : 442).

Dahrendrof menganalisis konflik dengan mengidentifikasikan berbagai peranan dan kekuasaan dalam masyarakat. Pertentangan terjadi karena dua golongan saling bertentangan, yaitu golongan yang berkuasa dan golongan yang dikuasai. Pertentangan terjadi karena golongan kuasa memertahankan status quo, sedangkan yang dikuasai berusaha melakukan perubahan-perubahan. Pertentangan ini selalu ada setiap waktu dan setiap struktur (Wirawan, 2012:88).

\section{METODE PENELITIAN}

Studi ini menggunakan metode penelitian Sejarah Kritis. Metode Sejarah Kritis dapat dibagi atas empat tahapan. 1) Heuristik atau pengumpulan sumber. 2) Verifikasi, melakukan kritik pada sumber yang telah ditemukan guna memvalidasi keabsahan sumber. 3) Interpretasi, yakni usaha menafsirkan ulang atau memberi makna pada sumber sejarah yang telah diverifikasi, dan 4) Historiografi, yakni melakukan rekonstruksi atas penulisan sejarah (Abbas, 2014: 38-39). Dalam mengumpulkan sumber-sumber tersebut, penulis menggunakan teknik library research, pembacaan dokumen, serta melakukan wawancara terhadap tokoh adat Sembalun dan sejumlah para petani Sembalun.

Tabel 1. Narasumber

\begin{tabular}{cccccc}
\hline No. & Nama & Umur & Pekerjaan & $\begin{array}{c}\text { Alamat } \\
\text { Wawancara }\end{array}$ & $\begin{array}{c}\text { Tanggal } \\
\text { Wawancara }\end{array}$ \\
\hline 1. & Amak Piran & 38 tahun & $\begin{array}{c}\text { Petani Sembalun } \\
\text { dan Ketua AGRA } \\
\text { cabang Sembalun }\end{array}$ & $\begin{array}{c}\text { Desa Sembalun } \\
\text { Timba Gading }\end{array}$ & 6 November 2020 \\
\hline 2. & Amak Reli & 55 tahun & Petani Sembalun & $\begin{array}{c}\text { Lahan Aur Ketu } \\
\text { Sembalun }\end{array}$ & 11 November 2020 \\
\hline 3. & Amak Rusniati & 60 tahun & Petani Sembalun & $\begin{array}{c}\text { Desa Sembalun } \\
\text { Timba Gading }\end{array}$ & 17 November 2020 \\
\hline
\end{tabular}




$\begin{array}{ccccc}\text { 4. } \begin{array}{c}\text { Abdulrahman } \\ \text { Sembahulun }\end{array} & 66 \text { tahun } & \begin{array}{c}\text { Petani Sembalun } \\ \text { Ketua Adat Tanaq } \\ \text { Sembalun }\end{array} & \text { Desa Sembalun } & 3 \text { November 2020 } \\ & & \end{array}$

Sumber: Wawancara penelitian, 2020.

\section{HASIL DAN PEMBAHASAN}

Terjadinya konflik agraria umumnya adalah akibat reaksi masyarakat atas perampasan lahan yang tengah mereka alami. Perampasan yang terjadi acap kali karena tidak diakuinya sistem kepemilikan lahan yang berlaku di masyarakat selama turun-temurun. Hal itu juga terjadi pada masyarakat petani di Kecamatan Sembalun. Pengalienasian sistem hukum adat dalam tata pengelolaan agraria yang dilakukan pemerintah Orde Baru telah menimbulkan sengketa antara masyarakat dengan pemerintah dan dengan perusahaan. Bagaimanapun konflik agraria yang terjadi di Kecamatan Sembalun tidak ada yang sepenuhnya natural atau tidaklah alami, melainkan efek dari konfigurasi aktivitas manusia. Dengan kata lain, ada faktor-faktor pendorong yang menjadi basis terbentuknya konflik agraria tersebut.

\section{Faktor-faktor Terjadinya Konflik Agraria Di Sembalun}

Pemerintah Orde Baru, dalam upaya melakukan kapitalisasi di wilayah pedesaan menganggap sistem hukum adat adalah penghalang bagi kebijakan yang dijalankan. Hal itu menjadi pertentangan yang membuat pemerintah menerapkan kebijakan dengan pendekatan stabilitas keamanan represif dan korporatis. Oleh karena pertentangan dengan sistem hukum adat itu pula, pemerintah berupaya menegasi sistem hukum adat dengan meminggirkan secara sistematis pengaruh kepemimpinan adat. Hal itu dilakukan dengan menghadirkan secara lebih kuat kepemimpinan birokrasi dan menerapkan penyeragaman struktur Pemerintahan Desa melalui deregulasi penerbitan UU No. 5 tahun 1979 tentang Pemerintahan Desa.

Dalam konteks dialektika historis masyarakat Sembalun, sistem hukum adat adalah tesis yang telah dilegitimasi oleh UUPA 1960 dan land reform - kini diperhadapkan dengan UU Pemerintahan Desa (UUPD) 1979 sebagai antitesisnya. Adanya antitesis penerbitan UUPD 1979 tersebut, menjadikan pemerintah Orde Baru berhasil mengubah struktur hukum adat dan menghilangkan segala aspek keragaman lokalitas, sekaligus mengubah sistem pengelolaan tanah masyarakat Sembalun. Dengan begitu, sistem hukum adat masyarakat Sembalun mengalami keteralienasian dalam tata pengelolaan agraria di Sembalun.

Peran pemimpin adat pun beralih fungsi menjadi bagian dari administrasi dalam kegiatan pemerintahan. Pemimpin adat Sembalun yang awalnya disebut Pemekel berubah menjadi Kepala Desa, Pemangku menjadi Lembaga Ketahanan Masyarakat Desa, dan Penghulu berubah menjadi Lembaga Musyawarah Desa (Yamni, 2015: 14). Perubahan pada lembaga adat ini menunjukkan adanya dominasi birokrasi pemerintahan, dan merupakan suatu kontrol negara terhadap kekuatan masyarakat hukum adat. Di lain sisi, para pemimpin adat tidak berdaya menghadapi kontrol negara, mereka cenderung mengabaikan kewajibannya dan bersekongkol dengan kepentingan pemerintah untuk tujuan komersil (Sembahulun \& Franky, 2009: 156). 
Melalui penerbitan UUPD 1979, sistem hukum adat masyarakat Sembalun dinegasi, diubah, dan disatukan oleh ketidakbebasan yang dipaksakan. Penegasian yang mengubah sistem pengelolaan agraria dan struktur hukum adat itu membuat masyarakat Sembalun jatuh ke dalam pertentangan dua sistem kepemimpinan. Satu sisi secara historis, masyarakat Sembalun sudah terbiasa hidup sosial dengan sistem hukum adat. Akan tetapi di lain sisi mereka harus taat pada perundang-undangan yang dibuat negara. Pertentangan itu mengakibatkan ketegangan pada masyarakat Sembalun, antara ikut ke dalam struktur negara yang memegang wewenang kekuasaan, atau tetap dalam struktur hukum adat sebagai dialektika historisitas mereka. Akan tetapi karena kekuasaan itu adalah sah, maka setiap individu ataupun masyarakat yang tidak tunduk pada wewenang tersebut akan dikenai sanksi.

Jadi, UUPD 1979, tidak hanya mengalienasi sistem hukum adat dari tata pengelolaan agraria di Sembalun, namun juga membuat masyarakat Sembalun itu sendiri teralienasi dari adat istiadatnya. Tanda dari keteralienasian itu adalah eksistensi negara sebagai lembaga dari luar dan dari atas memaksa individuindividu masyarakat Sembalun untuk bertindak sosial sesuai dengan peraturan perundang-undangan yang dibuat. Sementara individu-individu dalam masyarakat Sembalun itu sendiri semata-mata bertindak egois, dalam arti tindakan sosial mereka adalah berdasarkan sistem adat istiadat. Alienasi dari sistem adat ini secara simultan juga menandakan bahwa masyarakat Sembalun teralienasi dari sifatnya yang sosial, karena andai kata masyarakat Sembalun itu sosial dengan sendirinya, tidak perlu ada peraturan perundang-undangan dari negara yang memaksa mereka bersifat sosial (Suseno, 1999: 79).

Negasi yang mengalienasi sistem hukum adat itulah yang menyebabkan konflik agraria. Pemerintah telah mengambilalih semua tanah yang sebelumnya dimiliki oleh masyarakat adat dan menjadikannya tanah negara (negaraisasi), karena tidak bersertifikat. Hak pengelolaan atas tanah-tanah tersebut kemudian diberikan kepada korporasi atau pemodal, dalam hal ini adalah PT. SKE yang waktu itu dibawah pimpinan Tien Soeharto (istri Soeharto), seluas kurang lebih 555,56 hektar. Praktik negarasasi dan kapitalisasi tersebut membuat sistem hukum adat dan keadaan kehidupan masyarakat Sembalun memburuk, karena ketiadaan lahan sebagai alat poduksi memenuhi kebutuhan nafkah hidup material mereka pemuasan akan ekonomi. Akibat dari keadaan itulah yang menjadi faktor utama pemicu konflik agraria di tengah-tengah masyarakat Sembalun hingga saat ini.

Jadi, negasi terhadap sistem hukum adat telah menyebabkan masyarakat petani Sembalun kehilangan alat produksi materialnya, sehingga di waktu yang sama sistem kapitalisme dan praktik negarasasi itu telah meniadakan kesempatan masyarakat untuk bekerja. Dengan kata lain, sistem itu merampas harapan dan hak masyarakat Sembalun untuk menguasai pekerjaan mereka sendiri sebagai petani. Dalam rangka untuk memenuhi kebutuhan nafkah hidup material dirinya dan keluarganya, mereka mengalami kebingungan mencari lahan produksi untuk bercocok tanam. Pasalnya, lahan untuk memproduksi bahan pangan nyaris sudah tidak ada, sehingga distribusi pangan pun tidak terpenuhi. Sementara produksi dan distribusi itu menjadi sumber pendapatan masyarakat. Dengan begitu, ketiadaan lahan sebagai alat produksi juga telah mengakibatkan perekonomian masyarakat Sembalun mengalami demosi. 
Lambat laun masyarakat petani Sembalun pun mulai menyadari keadaan mereka yang teralienasi dari sistem hukum adat, dan alam lingkungannya sendiri akibat perampasan alat produksi material alam; hutan serta lahan tersebut. Dalam konsepsi materialisme dialektis, kesadaran masyarakat atas suatu keadaan yang mereka alami tersebut merupakan produk tertinggi manusia. Oleh karena itu, Karl Marx mengatakan bahwa "bukan kesadaran masyarakat yang menentukan keadaan mereka, tetapi sebaliknya keadaan sosial merekalah yang menentukan kesadaran mereka (Farihah, 2015: 34). Dengan kata lain, kesadaran adalah suatu hal yang sekunder, diturunkan dari materi. Jadi, yang menentukan perkembangan masyarakat bukan apa yang mereka pikirkan tentang dirinya sendiri, melainkan keadaan nyata dari masyarakat itulah yang menciptakan kesadarannya.

Masyarakat petani Sembalun pun mulai saling merasakan suatu kesamaan keadaan keteralienasian dan ketertindasan dari otoritas yang mengambilalih lahan mereka. Suatu perasaan serta pengalaman yang sama itu menciptakan kesadaran, bahwa mereka merupakan satu kelompok kelas senasib sepenanggungan sebagai petani Sembalun yang teralienasi-tertindas. Oleh karena itu, mereka sepakat untuk berintegrasi dan tidak hanya sekadar memahami keteralienasian dan ketertindasan itu, namun mulai mengusahakan perihal bagaimana melakukan emansipasi diri dari keadaan keteralienasian dan ketertindasan.

Ketika masyarakat mulai menyadari bahwa perampasan alat produksi materialnya telah menyebabkan mereka mengalami keadaan alienasi dari hukum adat dan alam lingkungannya sendiri, maka secara simultan kesadaran berintegrasi itu menciptakan pertentangan kekuatan produksi dan hubungan produksi antara masyarakat petani Sembalun dengan otoritas; negara atau kelas kapital, terutama dalam bidang ekonomi. Pertentangan ini adalah awal dari kontradiksi intern yang menyertai setiap fenomena kejadian materialisme. Secara sinambung, kontradiksi yang terjadi di dalam arena agraria ini pun sudah tidak lagi dapat dibendung, sehingga memunculkan suatu keadaan baru yang telah dinegasikan. Keadaan baru itu adalah lahirnya konflik akibat pertentangan kepentingan dari dua kelas sosial; antara masyarakat petani Sembalun dengan otoritas; negara maupun kelas kapital.

Keadaan itu yang kemudian disebut dengan konflik kepentingan di antara kelas-kelas sosial. Dalam hal ini, Marx berpendapat bahwa motor perubahan dan perkembangan masyarakat adalah petentangan antara kelas-kelas sosial dan kelaskelas sosial itu merupakan aktor sejarah sebenarnya. Jadi, jalannya sejarah bukan ditentukan oleh individu-individu tertentu, melainkan oleh kelas-kelas sosial yang masing-masing sedang memerjuangkan kepentingan mereka (Suseno, 1999: 126). Contoh dalam hal ini, adalah aksi-aksi demonstrasi yang dilakukan masyarakat petani Sembalun untuk menolak PT. SKE masuk kembali ke Sembalun, seperti yang sudah disebutkan di atas, merupakan suatu bentuk upaya dari masyarakat dalam memerjuangkan kepentingan mereka untuk memertahakan lahan. Pada titik inilah sejarah selalu bergerak dalam rangka kepentingan kelas sosial mereka, serta mencerminkan struktur kekuasaan kelas-kelas sosial di dalam masyarakat yang bersangkutan.

Dengan demikian, apabila diandaikan bahwa sekelompok orang selalu bertindak berdasarkan kepentingan primer untuk memertahankan diri, maka dalam 
konteks pertentangan kepentingan di Sembalun dapat dirumuskan begini: Kelas kapital ataupun otoritas yang ingin memeroleh laba lebih selalu berkepentingan memertahankan kedudukan mereka dalam menguasai alat produksi material; alam hutan dan lahan masyarakat petani Sembalun dengan memerpanjang HGU yang sudah habis. Sebaliknya, masyarakat Sembalun berkepentingan memerjuangkan emansipasi atas alam hutan dan lahan untuk mengubah keadaan mereka yang teralienasi, sehingga bisa memenuhi kebutuhan nafkah hidup materialnya.

Berdasarkan gugusan pengalaman kolektif, usaha untuk emansipasi itu terumuskan dalam misi dan semangat perjuangan masyarakat petani Sembalun sebagai kelas tertindas; kaum yang tidak punya lahan, tidak punya alat produksi. Usaha emansipasi dilakukan melalui perjuangan kelas yang menjadi konsensus sebagai misi bersama untuk memerjuangkan kepentingan hak atas alat produksi material; untuk menguasai pekerjaan mereka sendiri, yaitu mengerjakan alam, mengolah hutan dan menghijaukan lahan-lahan sawah sebagai wujud dari petani yang nyata. Dengan hanya alat produksi itu, masyarakat petani Sembalun bisa benar-benar memenuhi kebutuhan nafkah hidup material dirinya dan keluarganya.

Konsensus tersebut tidak akan muncul bila masyarakat petani Sembalun tidak berintegrasi. Integrasi pun tidak akan terjadi bila tanpa ada keadaan yang menciptakan suatu perasaan yang sama. Semua konsensus dan integrasi ini tidak akan terjadi bila tidak ada konflik yang menjadi persyaratan satu sama lain (Bima dkk., 2018: 10). Integrasi dan konsensus masyarakat petani Sembalun untuk emansipasi yang terumus dalam misi dan semangat melalui perjuangan kelas itu, menjadi negasi atas negasi; penyangkalan atas peyangkalan; dan sebuah formulasi sintesis untuk mengadakan perubahan.

Pada gilirannya, dialektika penolakan atas penolakan ini membawa sebuah kemajuan terus-menerus, bahwa setiap konflik akan menghasilkan suatu formulasi baru (Ramly, 2000: 121). Sebagaimana Dahrendorf menyebutkan bahwa segera setelah kemunculan kelompok konflik, kelompok tersebut melakukan tindakan yang menyebabkan perubahan dalam struktur sosial. Apabila konflik itu hebat, perubahan yang terjadi akan radikal. Apabila konflik disertai tindakan kekerasan, akan terjadi perubahan struktur secara tiba-tiba. Jadi, konflik juga menyebabkan perubahan dan perkembangan di dalam masyarakat (Rahmaniah, 2001: 16).

Akhirnya, dibalik konflik serta pertentangan di Sembalun yang didasari oleh kesadaran masyarakat akan keadaannya yang teralienasi-tertindas, terdapat kelaskelas sosial yang memerjuangkan kepentingan mereka masing-masing. Satu kelas tetap menindas segala bentuk ancaman terhadap kedudukan mereka demi memertahankan status quo, dan satu kelas yang lain berusaha membebaskan diri dari ketertindasan itu. Pertentangan antara dua kelas sosial inilah yang kemudian menjadi penanda kemunculan kelompok konflik (Kasim \& Abidin Nurdin, 2015: 42). Inilah dialektika pertentangan kepentingan bahwa semua benturan sejarah adalah berasal dari pertentangan antara tenaga-tenaga produksi material dan hubungan-hubungan sosial. Dialektika ini tidak akan pernah selesai hingga terbentuknya suatu masyarakat tanpa kontradiksi, karena masyarakat petani yang sadar terhadap keadaannya akan selalu melawan segala bentuk ancaman yang membuat mereka teralienasi dan tertindas. 


\section{Bentuk-bentuk Konflik Agraria Di Sembalun}

Konflik agraria yang terjadi di Kecamatan Sembalun bersumber dari tidak berlakunya Undang-Undang Pokok Agraria (UUPA) tahun 1960, dan penerapan penyeragaman struktur Pemerintahan Desa melalui UU No. 5 tahun 1979. Hal itu berakibat pada proses pengalienasian struktur hukum adat di dalam masyarakat Sembalun. Aset desa Sembalun yang sebagian besar dalam perlindungan hukum adat, mengalami banyak pelepasan oleh otorisasi negara yang mengabaikan peran hukum adat. Akibatnya, banyak aset tanah ulayat yang lepas kepemilikannya dari komunitas masyarakat adat (Rozaki, 2016: 40).

Berdasar hasil wawancara dengan Abdulrahman Sembahulun (2020) yang merupakan Ketua Adat Tanaq Sembalun, pada 1979 masyarakat adat dikeluarkan dari lahannya. Setelah mengambilalih lahan masyarakat, pemerintah lalu membagi lahan tersebut menjadi dua fungsi, yaitu sebagian menjadi suaka marga satwa dan sebagian menjadi tanah milik negara. Kebijakan dalam pengelolaan agraria yang tidak mengacu pada sistem hukum adat menyebabkan masyarakat mengalami kerugian. Keadaan itu memicu masyarakat bereaksi dengan merusak sekeliling lahan yang mereka kerjakan. Masyarakat yang merasa terpinggirkan juga merusak yang lainnya sehingga terjadilah illegal logging, karena masyarakat merasa memiliki hak atas lahan tersebut.

Setelah diterbitkannya UU Desa 1979, di tahun yang sama masyarakat Sembalun membentuk sebuah organisasi Ikatan Pemuda Peduli Sembalun (IPPS). Tujuan dari dibentukya IPPS adalah untuk membangun paham dan kesadaran masyarakat Sembalun, khususnya kaum muda terhadap keadaan yang timpang akibat peralihan fungsi lahan, dan bergesernya nilai-nilai adat serta kearifan lokal setempat. Pembentukan oganisasi ini sekaligus juga sebagai strategi perlawanan atas dominasi otoritas. IPPS pun menjadi wadah perjuangan pertama di Sembalun untuk memertahankan lahan dan mengembalikan sistem hukum adat dalam tata pengelolaan agraria.

Sekalipun masyarakat Sembalun telah membentuk IPPS, tetapi pemerintah yang memegang otoritas masih dengan mudah mengubah status tanah masyarakat adat menjadi tanah negara. Awal dari kejadian itu adalah tahun 1980, saat petugas Dinas Kehutanan dan Perkebunan (Dishutbun) menawarkan kerjasama kepada masyarakat Sembalun untuk menjalankan proyek penanaman kopi. Yamni (2015: 2), mencatat sebuah keterangan dari Muliono, salah seorang petani Sembalun yang ikut dalam proyek penanaman kopi, yang didatangi oleh dua orang pihak Dishutbun. Kepada Muliono pihak Dishutbun menawarkan akan menyediakan bibit kopi sesuai dengan luas lahan yang dikerjakannya. Penawarannya pun sangat menggiurkan, yakni jika hasil tanaman kopi bagus, keuntungan bisa dinikmati oleh sang penanam. Jika terjadi gagal panen, masyarakat tidak perlu membayar ganti rugi kepada pemerintah.

Proyek penanaman kopi tersebut rupanya juga bekerjasama dengan Bank Bukopin. Dalam kerjasama itu, sebagian masyarakat ada yang mendapat sejumlah uang. Ada yang dapat 500 ribu rupiah per Kartu Keluarga, ada yang hanya dapat 100 ribu, dan ada pula yang sama sekali tidak mendapat uang. Ketika proyek penanaman kopi sudah berlangsung, menurut keterangan Amaq Reli (2020), salah 
satu petani Sembalun yang ikut proyek penanaman kopi, proyek penanamman kopi tersebut dimanfaatkan oleh Petugas Penyuluh Lapangan (PPL) bagian perkebunan, yang bernama Kirno. Proyek kopi pun gagal panen, dan secara das sein masyarakat diminta membayar atas kegagalan itu dengan cara melepaskan lahan-lahannya kepada pemerintah.

Dalam catatan Yamni (2015: 3), sejumlah masyarakat Sembalun yang akhirnya kehilangan lahannya tersebut, di antaranya: Haji Nasruddin, ketua proyek penanaman kopi kehilangan lahan seluas 60 are; Amaq Sarihin kehilangan lahan satu hektar 90 are; Amaq Darmaim, Amaq Karnaen, Amaq Ciok, serta Amaq Apti sama-sama kehilangan satu hektar lahan, dan masih banyak yang lainnya. Akibat kasus ini, banyak masyarakat Sembalun menjadi miskin karena tidak lagi mempunyai lahan sebagai alat produksi yang bisa menghasilkan bahan pangan. Akhirnya demi memertahankan eksistensi, masyarakat pun mengonsumsi gadung yang pada waktu itu menjadi satu-satunya makanan alternatif di Sembalun (Yamni, 2015: 4).

Demikianlah cerita dari kerjasama penanaman kopi yang berlangsung tahun 1980 tersebut, yang berakhir sebagai tragedi bagi masyarakat Sembalun. Perjanjian untuk masyarakat tidak perlu membayar ganti rugi jika terjadi gagal panen, hanya jadi gurauan belaka. Melalui Dishutbun terjadilah pengambilalihan lahan milik masyarakat, karena dianggap berhutang atas kegagalan penanaman kopi tersebut. Masyarakat yang merasa dicurangi oleh dinas terkait pun tidak bisa berbuat apaapa. Pasalnya, masyarakat yang menolak menyerahkan lahannya mendapat teror dan ditakut-takuti. "Karena kita ditakut-takuti, kalau gak mau menyerahkan tanahnya, disidang, dibawa ke Selong (pengadilan)," kata Amaq Reli (2020).

Mengingat kejadian tersebut di atas, membuat anggota IPPS tidak hanya sebatas dari pemuda. Akan tetapi juga melibatkan golongan tua yang mulai sadar dengan kondisi Sembalun yang lahan-lahannya telah beralih fungsi, dan nilai-nilai adat serta kearifan lokalnya telah bergeser. Dengan terlibatnya golongan tua dan muda dalam satu bentuk kolektivitas gerakan, maka dibentuklah sebuah aliansi bernama Aliansi Masyarakat Adat Lombok (AMAL) pada 1982, yang kemudian tahun 1999 menjadi bagian dari Aliansi Masyarakat Adat Nusantara (AMAN) (Wawancara dengan Abdulrahman Sembahulun, 2020). Akan tetapi dihadapan supremasi Orde Baru, AMAL juga tidak mampu memertahankan lahan yang diambilalih pemerintah melaui pemberian HGU kepada korporasi.

Mengingat orientasi agraria pemerintah Orde Baru adalah mendukung investasi-investasi skala besar. Oleh karena itulah lahan dalam skala besar untuk kepentingan modal dalam negeri maupun luar negeri menjadi prioritas yang harus disediakan. Dengan begitu, pemerintah dapat memfasilitasi korporasi dengan memberikannya HGU. Salah satu HGU yang diberikan pemerintah pada korporasi adalah lahan masyarakat Sembalun yang telah diambilalih. Hal itulah yang lantas menyebabkan sengketa antara masyarakat Sembalun dengan pemerintah dan korporasi. Persengketaan ihwal HGU di Sembalun itu bermula dari kedatangan Soeharto dalam rangka panen raya bawang putih tahun 1987. Tidak lama setelah itu, di tahun 1988, masyarakat Sembalun mendengar kabar bahwa tanah tempat mereka menanam bawang putih telah dibeli oleh Tien Soeharto (istri Soeharto) melalui PT. SKE dengan seorang makelar tanah. Pada waktu itu, tanah yang 
digunakan untuk menanam bawang putih telah dikerjakan oleh sekitar 100 petani, dan 20 di antaranya sudah memiliki sertifikat tanah (Ramdani, 2017: 3).

Akan tetapi menurut keterangan Amaq Rusniati (2020), salah satu petani Sembalun yang lahannya masuk ke dalam wilayah sengketa, bahwa PT. SKE yang dibantu oleh Pemerintahan Desa dan Kabupaten tetap melakukan pembebasan lahan dengan memberi sejumlah uang ganti rugi kepada masyarakat supaya mau menyerahkan lahannya. PT. SKE kemudian melakukan uji coba penanaman bawang putih di atas lahan tersebut. Akan tetapi mengalami kegagalan akibat kekurangan pasokan air. Pasca kegagalan itu, PT. SKE mengupayakan untuk memeroleh jenis tanaman lain yang dapat dibudidayakan dengan kondisi sumber air di Sembalun. Akan tetapi beberapa tahun sudah terlewat dan pihak PT. SKE juga belum berhasil memeroleh jenis tanaman lain yang akan dibudidayakan. Hal itu membuat lahan ratusan hektar bekas tanam bawang putih PT. SKE menjadi terlantar, sebab tiada yang mengelola.

Melihat luas lahan yang terlantar selama beberapa tahun itu, akhirnya membuat puluhan masyarakat petani setempat sepakat melakukan pengerjaan lahan terlantar tersebut. Dalam hal ini, tahun 1996 Abdulrahman Sembahulun melalui Pondok Pesantren Pertanian yang didirikannya secara resmi mengirimkan surat permohonan kepada PT. SKE untuk mengerjakan lahan terlantar tersebut. Akan tetapi surat permohonan itu tidak mendapat respon dari pihak perusahaan, sehingga mereka tetap mengerjakan lahan tersebut. Awalnya memang hanya sedikit orang yang ikut dalam pengerjaan lahan terlantar tersebut, sehingga tidak terlalu menghasilkan. Akan tetapi melaui pengumuman di masjid, Amaq Rusniati kemudian mengajak lebih banyak orang. Selain karena kondisinya yang terlantar, aksi pengerjaan lahan PT. SKE tersebut juga disebabkan oleh krisis moneter tahun 1997 yang menimpa Indonesia. Hal ini sebagaimana halnya alasan Amaq Rusniati (2020), "Kalau tidak ada krisis itu, mungkin kami gak akan masuk ke sana (lahan terlantar PT. SKE)."

Sejak pengambilalihan lahan di tahun 1980 dan 1990, membuat sebagian besar masyarakat petani Sembalun memang tidak lagi mempunyai lahan; tidak lagi memiliki alat-alat produksi dan sarana kerja. Akhirnya demi keberlangsungan hidup di tahun-tahun ketika Indonesia mengalami krisis moneter, ada sebagian masyarakat petani Sembalun yang melakukan pengerjaan lahan terlatar PT. SKE. Ada pula sebagian yang menjadi pekerja upahan di perusahaan Sampoerna Agroyang menjalin kerjasama dengan PT. SKE dalam pengelolaan lahan di Sembalun. ${ }^{1}$ Menjadi pekerja upahan berarti mereka menjual tenaga kerjanya pada kelas kapital (yang menguasai alat produksi) demi memeroleh upah. Hal itu meminjam istilah Magnis Suseno (1999: 115) merupakan pekerjaan kaum tertindas; sebab harapan dan hak menguasai pekerjaan mereka sendiri dirampas. Jadi, hasil kerja dan kegiatan bekerja bukan lagi milik pekerja itu sendiri, tetapi milik perusahaan yang menjadi majikan.

Mereka yang bekerja hanya demi memeroleh upah tidak bekerja untuk pekerjaan itu sendiri, dan tidak pula demi mengembangkan diri, melainkan hanya

${ }^{1}$ Perusahaan Sampoerna Agro mendapat lahan dari PT. SKE pada 1999 yang digunakan sebagai areal pembangunan Green House Hortikultura untuk pasar ekspor. 
sebagai syarat untuk bisa bertahan hidup di tengah ketiadaan alat produksi, ketiadaan sarana kerja dan krisis bahan pangan. Jadi, pekerjaan yang dilakukan sebagian masyarakat petani Sembalun di perusahaan Sampoerna Agro itu tidak mengembangkan dirinya, namun justru mengasingkan mereka. Mereka terasing dalam pekerjaannya karena tidak dapat bekerja secara bebas dan universal, sesuai hasrat dan dorongan batin. Pekerjaan itu mereka lakukan karena terpaksa, karena semata-mata hanya demi memeroleh upah sehingga harus menerima pekerjaan apa saja yang telah diperintahkan oleh perusahaan. Dengan demikian, tindakan bekerja itu sendiri pun kehilangan arti bagi si pekerja upahan. Pasalnya, pekerjaan itu bukanlah kebutuhan bagi si pekerja, melainkan mereka bekerja hanya untuk memertahankan kehidupan fisik dan supaya tidak kelaparan.

Keadaan dari sebagian masyarakat petani Sembalun yang menjadi pekerja upahan tersebut di atas tidak berlangsung lama, karena banyak dari mereka yang kemudian diputus hubungan kerja (PHK) oleh perusahaan (Rozaki, 2016: 41). Implikasi dari PHK tersebut membuat keadaan pertentangan antara masyarakat petani dengan korporasi justru menuju proses dialektika yang mengandung benih perkembangan, sehingga pertentangan itu semakin tajam. Demi memenuhi nafkah hidup material, masyarakat petani Sembalun yang di PHK, banyak yang kemudian ikut dalam pengerjaan lahan terlantar PT. SKE sejak mengalami kegagalan dalam uji coba penanaman bawang putih. Faktor lain yang melatarbelakangi pengerjaan lahan terlantar tersebut adalah akumulasi dari konflik agraria, dan berlarutnya penyelesaian konflik yang berlangsung selama masa pemerintahan Orde Baru.

Saat pemerintah memfasilitasi korporasi dengan HGU, di saat yang sama pula banyak petani Sembalun kehilangan tanahnya, sehingga mereka pun menjadi petani yang tidak bertanah. Penetapan lahan untuk areal HGU di Sembalun, jelas tidak menguntungkan masyarakat secara ekonomi. Banyak pemanfaatan tanah yang sama sekali tidak berkontribusi pada peningkatan ekonomi masyarakat. Hasil pemanfaatan tanah justru hanya dinikmati pemerintah dan pemodal pemilik perusahaan. Karakter perlakuan yang lebih mementingkan pemodal seperti itulah yang akhirnya memicu aksi masyarakat melakukan pengerjaan lahan PT. SKE, sebagai bentuk resistansi terhadap kebijakan negara yang tidak memihak mereka.

Konflik tersebut terus berlanjut dengan aksi-aksi yang lebih sistematik dan terbuka pasca runtuhnya Orde Baru. Aksi berawal dari tahun 2014, ketika pihak PT. SKE dalam rangka memerpanjang HGU yang sudah habis memasang plang-plang di setiap lahan yang hendak dikuasainya kembali setelah dikerjakan oleh masyarakat. Aksi pemasangan plang oleh PT. SKE itu langsung menuai reaksi dari masyarakat petani Sembalun. Menurut keterangan Amaq Piran (2020), salah satu petani Sembalun dan Ketua AGRA cabang Sembalun, hampir setiap malam sekitar 500-600 orang berkumpul, mengadakan pertemuan di masjid-masjid untuk membahas dan bermusyawarah perihal yang mesti dilakukan terkait pemasangan plang oleh PT. SKE.

Dalam musyawarah tersebut, Amaq Piran menyarankan untuk melakukan long march atau demonstrasi ke Kantor Camat Sembalun. Saran itu rupanya diterima oleh masyarakat petani Sembalun. Ihwal tentang aksi tersebut, Amaq Piran (2020) mengatakan bahwa sekitar 3.000 massa mengepung Kantor Camat Sembalun. Aksi tersebut akhirnya mengarah pada pencabutan plang-plang yang 
dipasang pihak PT. SKE oleh masyarakat. Aksi demonstrasi tahun 2014 tersebut, adalah awal dari rentetan aksi-aksi demonstrasi lanjutan pada tahun-tahun berikutnya.

Pasca 2014, masyarakat Sembalun selalu melakukan aksi untuk menolak PT. SKE kembali masuk ke Sembalun. Pada 2015, aksi demonstrasi dilakukan oleh masyarakat petani Sembalun saat mengetahui pada 21 Oktober 2015, pihak Badan Pertanahan Nasional Nusa Tenggara Barat (BPN NTB) melakukan pengukuran ulang dan pemetaan bidang tanah HGU PT. SKE. Masyarakat yang khawatir dengan kegiatan BPN NTB tersebut, kemudian berbondong-bondong mendatangi kantor DPRD Kabupaten Lombok Timur untuk menolak PT. SKE kembali masuk ke Sembalun. Pasalnya, jika kontrak sampai terjadi, masyarakat Sembalun terancam kehilangan mata pencaharian. Tuntutan ratusan petani penggarap ini disampaikan pada aksi 4 November 2015, bersama dengan sejumlah organisasi masyarakat, seperti Aliansi Gerakan Reforma Agraria (AGRA) cabang Sembalun, Pemuda Adat Sembalun, Masyarakat Adat Tanak Sembalun, dan Aliansi Masyarakat Adat Nasional (dalam lombokfm.com/warga-sembalun-tolak-kontrakpt-ske, akses 4 September 2020).

Pada 13 April 2016, dalam rangka menolak perpanjangan HGU PT. SKE, masyarakat Sembalun berdemonstrasi di kantor BPN NTB. Tujuan aksi ini adalah supaya BPN NTB tidak mengeluarkan surat perpanjangan izin HGU PT. SKE (Pratama, 2016). Pada 26 September 2016, elemen masyarakat yang tergabung dalam Front Perjuangan Rakyat (FPR) NTB menggelar demonstrasi di Kantor Gubernur NTB. Ada 19 tuntutan dalam aksi ini, salah satunya adalah menolak perpanjangan HGU PT. SKE di Sembalun (dalam suarantb.com/massa-gelar-aksidi-kantor-gubernur-ntb/, akses 4 September 2020).

Aksi demonstrasi menolak perpanjangan HGU PT. SKE dari masyarakat petani Sembalun terus berlanjut sampai tahun 2019, yakni pada 29 Oktober ratusan anggota kelompok tani Sembalun menggelar kembali aksi di Kantor Camat Sembalun. Pada aksi tersebut, empat kepala desa yang ikut hadir mengaku berada dipihak masyarakat sejak awal. Aksi tersebut pun diakhiri dengan membuat Surat Pernyataan Bersama yang ditanda tangani oleh empat Kepala Desa, di antaranya: Kepala Desa Sajang (H. Lalu Kanahan), Kepala Desa Sembalun Lawang (H. M. Idris), Kepala Desa Sembalun (Harmini), dan Kepala Desa Sembalun Timba Gading (Ridwan Hardi). Surat pernyataan bersama tersebut menyatakan bahwa empat kepala desa tersebut, ikut mendukung harapan dan keinginan masyarakat, karena PT. SKE tidak layak untuk diperpanjang izin HGU dan PT. SKE tidak melaksanakan aktivitas sesuai dengan konsep dan tujuan sejak awal (Surat Pernyataan Bersama Empat Kepala Desa di Kecamatan Sembalun, 6 November 2019).

Menurut Amaq Piran (2020) aksi akan terus dilakukan sampai pemerintah benar-benar mengakui lahan masyarakat secara de jure dan de facto. Pasalnya, lahan yang masyarakat garap selama berpuluhan tahun itu menjadi tempat menggantungkan hidup, memenuhi nafkah keluarga. Oleh karena itu, masyarakat berkonsensus untuk terus berjuang memertahankan lahannya, dan sekaligus menegaskan bahwa petani Sembalun menolak pengambilan lahan oleh pihak PT. SKE. 


\section{SIMPULAN}

Berdasarkan uraian yang telah disampaikan di atas dapat ditarik sebuah simpulan bahwa konflik agraria yang terjadi pada 1979-2019 di Kecamatan Sembalun merupakan bentuk konflik agararia struktural, yakni pertentangan klaim mengenai siapa yang berhak atas akses pada tanah dan sumber daya alam antara masyarakat petani Sembalun dengan otoritas; negara dan kelas kapital (korporasi). Bentuk konfliknya cukup beragam, ada yang memerhadapkan antara masyarakat dengan pemerintah, masyarakat dengan korporasi, serta antara masyarakat dengan pemerintah dan koporasi.

Konflik tersebut berimplikasi pada berbagai aspek, seperti sosial ekonomi, politik dan lingkungan. Implikasi lanjutan dari konflik membuat masyarakat membangun ikatan organisasi yang lebih kuat di antara sesama anggota, karena perasaan senasib sebagai pihak yang tertindas. Tidak hanya itu, akibat konflik agraria yang tidak mengusai itu dan minimnya akses atas lahan yang dimiliki membuat masyarakat banting setir, untuk tidak hanya bergantung pada pertanian atau perkebunan. Ada yang beralih hingga menjadi buruh migran ke luar negeri sebagai TKI untuk menopang keberlangsungan kehidupan keluarganya di desa. Selain itu, kerusakan alam di Sembalun juga terjadi. Degradasi alam itu ditandai dengan hilangnya sejumlah mata air, dan kebakaran hutan hampir setiap tahunya.

\section{REFERENSI}

Abbas, Irwan. 2014. "Memahami Metodologi Sejarah antara Teori dan Praktek," .Jurnal ETNOHISTORI, Vol. 1, No. 1, pp. 37-46.

Astuti, Puji. April 2012. "Kekerasan Dalam Konflik Agraria: Kegagalan Negara Dalam Menciptakan Keadilan Di Bidang Pertanahan," FORUM, Vol. 39, No. 2, pp. 52-60.

Bima, Khabib dkk. 2018. Teori Konflik: Sebuah Kajian Menuju Pemikiran Ralf Dahrendorf. Surakarta: Pascasarjana Sosiologi Fakultas Ilmu Sosial Dan Politik Universitas Sebelas Maret.

Dewi, Maria Seraphine Kartika. 2018. "Pengaturan Kewenangan Kementrian Agraria/Kepala Badan Pertanahan Nasional Dalam Mekanisme Penyelesaian Sengketa Hak Atas Tanah," Jurnal Hukum Kenotarian, Vol. 3, No. 4.

Fajar, Jay. 05 Desember 2014. "Ada Apa Dengan Adat Sajang Di Lereng Rijani? (Bagian II)," http://www.mongabay.co.id/2014/12/05/ada-apa-denganadat-sajang-di-lereng-rinjani-bagian-ii/ (akses 18 Januari 2020).

Farihah, Irzum. Desember 2015. "Filsafat Materialisme Karl Marx (Epistimologi Dialectical And Historical Materialism)," Jurnal Ilmu Aqidah dan Studi Keagamaan, Vol. 3, No. 2, pp. 34-43.

Fuadi. 2015. "Metode Historis: Suatu Kajian Filsafat Materialisme Karl Marx,"Jurnal Substantia, Vol. 17, No. 2.

Kartodirdjo, Sartono. 1993. Pendekatan Ilmu Sosial Dalam Metodologi Sejarah. Jakarta: PT Gramedia Pustaka Utama.

Kasim, Fajri M. \& Abidin Nurdin. 2015. Sosiologi Konflik dan Rekonsiliasi: Sosiologi Masyarakat Aceh. Aceh: Unimal Press. 
Lombokfm.com. 05 November 2015. "Warga Sembalun Tolak Kontrak PT SKE," https://lombokfm.com/warga-sembalun-tolak-kontrak-pt-ske.html (akses 4 September 2020).

Pratama, Dhimas Budi. 13 April 2016. "Warga Sembalun Tolak Perpanjangan HGU PT SKE," https://mataram.antaranews.com/berita/30319/wargasembalun-tolak-perpanjangan-hgu-pt-ske (akses 10 Februari 2020).

PT. Sembalun Kusuma Emas, "Penguasaan tanah kami di Sembalun oleh pihak lain," (Jakarta: 2 Maret 2009).

Rahmaniah, Aniek. 2001. "Teori Konflik: Ralf Dahrendorf," http://repository.uinmalang.ac.id/729/ (akses 5 Mei 2020).

Ramdani, Lestari. 14 Juli 2017. "Pemanfaatan Tanah HGU (Hak Guna Usaha) Yang Jangka Waktunya Telah Berakhir," Jurnal Ilmiah UNRAM, pp. 1-9.

Ramly, Andi Muawiyah. 2000. Peta Pemikiran Karl Marx (Materialisme Dialektis dan Materialisme Historis). Yogyakarta: Pustaka Sastra.

Rosana, Ellya. 2015. "Konflik Pada Kehidupan Masyarakat (Telaah Mengenai Teori Dan Penyelesaian Konflik Pada Masyarakat Modern)," Al-AdYaN, Vol. X, No. 2, pp. 216-226.

Rozaki, Abdur. Januari 2016. "Konflik Agraria, Perempuan Dan Kemiskinan Di Desa," Musãwa, Vol. 15, No. 1, pp. 38-52.

Sembahulun, Abdulrahman \& Y.L. Franky. 2009. Hutan Untuk Masa Depan: Pengelolaan Hutan Adat Di Tengah Arus Perubahan Dunia. Jakarta: AMAN \& DTE.

Suarantb.com. 26 September 2016. "Peringati Hari Tani, Dua Kelompok Massa Gelar Aksi di Kantor Gubernur NTB," https://www.suarantb.com/peringati-hari-tani-dua-kelompok-massagelar-aksi-di-kantor-gubernur-ntb/ (akses 4 September 2020).

Sujiwo, Tri Agung. 2010. "Dinamika Strategi Organisasi Tani Pasca-1965 Di Indonesia.” Jurnal Analisis Sosial, Vol. 15, No. 1.

Surat Pernyataan Bersama Empat Kepala Desa di Kecamatan Sembalun, pada 6 November 2019

Suseno, Franz Magnis. 1999. Pemikiran Karl Marx dari Sosialisme Utopis ke Perselisihan Revisionisme. Jakarta: PT Gramedia Pustaka.

Widyaningrum, Nurul et.al. 2010. "Aksi Petani dan Gerakan Politik Pedesaan," Jurnal Analisis Sosial, Vol. 15, No. 1.

Yamni. 2015. "Taman Suaka Marga Satwa Rinjani, Tanam Paksa Kopi, Taman Nasional Gunung Rinjani dan HGU: Negara(isasi) Tanah Masyarakat Adat Sembahulun dari Masa ke Masa," Working Paper Sajogyo Institute No. 3, pp. 1-26. 